\title{
Earmarking Tax Policy on Local Tax in Indonesia: Toward Pro Fiscal Legitimacy Policy (Study at Batu City, East Java and Special Province of Yogyakarta)
}

\author{
Inayati \\ Department of Fiscal Administration \\ FIA UI \\ Depok, Indonesia \\ Inayati.hifni01@gmail.com
}

\author{
Gunadi \\ Department of Fiscal Administration \\ FIA UI \\ Depok, Indonesia
}

\author{
Haula Rosdiana \\ Department of Fiscal Administration \\ FIA UI \\ Depok, Indonesia
}

\begin{abstract}
Earmarking tax is the concept of the allocation of expenditure from tax revenue that brings a number of pros and cons. In contrast to the concept of taxes that generally do not directly relate between taxes levied and government spending, earmarking taxes affirm the relationship between taxes and specific spending allocations. Opponents argue that earmarking tax causes the management of government spending to be inflexible, fragmented, inefficient and less effective because of inconsistencies between the allocation of spending and the needs of society. The proponents of the earmarking tax believe earmarking taxes contribute to strengthening the government's fiscal legitimacy in collecting and spending on tax revenues. In Indonesia, the earmarking tax policy has been regulated and implemented since 2010 through law no 28/2009 on Local Tax and Local Charges, as well as regional regulation. This research aims to analyze the implementation of earmarking tax policy on local taxes in the perspective of Fiscal Legitimacy with the case of Batu City and the Special Province of Yogyakarta. This research was conducted with constructivist paradigm, as well as qualitative approach and method. Primary data obtained through in-depth interviews with stakeholders and academics, then processed with qualitative data analysis techniques. Secondary data were obtained from literature and document studies. The results of research indicate that in general the policy/regulation of earmarking tax in Indonesia and its implementation in both research sites have not supported the strengthening of fiscal legitimacy. Thus, it is necessary to reconstruct the earmarking tax policy by strengthening the relationship between the types of local taxes and the allocation of expenditures. In addition, the government needs to revise the regulations on public finance management so that it harmonizes with the concept of earmarking tax and supports the strengthening of fiscal legitimacy.
\end{abstract}

Keywords—earmarking tax; local tax; fiscal legitimacy

\section{INTRODUCTION}

Tax is one of the crucial issues in the relationship between government and society. History records show the occurrence of a number of rebellions because the tax perceived unfair by the public. Conceptually there is also discussion among academics and tax practitioners about the relationship between taxes paid by society and the benefits they receive.

In contrast to the concept of charges, in general the tax is considered not to have a clear relationship with the benefits received by the community. Charges are government levies on the consumption of public goods and services by consumers, such as the price paid for the consumption of goods and services in the private sector (Musgrave and Musgrave, 1984; 1990). For example, the local government in Australia collects charges on infrastructure provided by the local government (Bryant, 2017).

In a more conservative perspective, taxes are defined as compulsory levies imposed by countries without benefits that can be directly observed by taxpayers (James, 1996; Sommerfeld, Anderson \& Brock, 1981; Hyman, 2013; James, 1996; Musgrave \& Musgrave, 2002; Rosdiana and Irianto, 2012). In this definition, taxes are designed to generate state revenues while providing flexibility for governments to allocate spending according to their priorities. Unfortunately, this characteristic makes taxpayers have weak bargaining positions in the allocation of government spending. Although on the other hand, the government has an obligation to improve the welfare of the community through proper allocation of public spending.

Taxes are more often discussed in relation to the ability to pay taxes (ability to pay principle). Although some experts such as Musgrave (1984), Abassian and Myles (2006) developed the idea of benefit taxation, a concept that links the tax burden to the benefits received by society from the government's (benefit principle). In this perspective, taxes are the price to be paid on transactions in the utilization of public goods or services (transactional taxation). Equity is assumed to be achieved if the taxes paid by society represent the benefits received from the government (Neil, 2000).

The weak link between taxes levied by the government and the perceived benefits of society, has the potential to undermine the government's fiscal legitimacy. Fiscal legitimacy is a reflection of the confidence of people grant their government's performance in collecting and spending its 
tax revenue "(OECD, 2007: 1m.1). Public confidence in the government's performance in collecting taxes and on spending performance is an important issue that determines the success of tax collection. The low level of fiscal legitimacy has some risks for the government, among others, the community's refusal to pay taxes.

Trandafir and Ristea (2013) asserted the urgency of legitimacy to support the efficiency of fiscal policy. In this perspective, legitimacy is associated with allocation in fiscal policy (Trandafir and Riesta, 2013), or government's expenditure quality. The Government may strengthen fiscal legitimacy among others by improving the quality of public expenditure to be more equitable and suitable for interests of taxpayers (OECD, 2007). Fiscal legitimacy can be understood by the perspective of Fiscal Contractual Theory, viewing the relation between taxpayers and the government as a contract between the two parties of which is obliged to either pay tax or provide public services (D'Arcy, 2011).

In this context, earmarking tax stressing about a relation between the collected tax and the benefits received by the people specifically from government expenditure is a crucial issue (Buchanan, 1963; Wilkinson, 1994; Bird and Jun, 2005)). However, the earmarking tax is also debatable. The proponents of earmarking tax suggest that it secures fund availability to provide particular public services or to improve the accountability of the use of tax revenue (Buchanan, 1963; Wilkinson, 1994;,Bo“s 2000; Michael, 2008). Politically, earmarking tax has some advantages in ensuring reliable and predictable fund availability to carry out government programs and improve support to the government in fundraising (Michael, 2008; Jackson, 2008).

In the implementation, earmarking tax seems to be more successful in the context of local government since there is a closer relation between the benefit recipients and taxpayers and public service users can more easily express their preference through political voting (Dhillon and Perroni, 2000) and therefore improve tax morale (Feld and Frey, 2007). In Indonesia, earmarking tax policy is regulated in Law of 28 / 2009 concerning Local Tax and Local Charges (Local Tax and Charges Law/2009). The tax types earmarked include Motor Vehicle Tax and Cigarette Tax in Province and Street Illumination Tax in regency/ city while not reserving the possibility for local governments to add the types of earmarked tax when it is deemed necessary. As the implementation of Law of PDRD / 2009, including in DIY Province and Batu City nearly all regions in Indonesia has accommodated earmarking tax policy. DIY Province regulates earmarked tax for Motor Vehicle Tax, Motor Vehicle Fuel Tax, Cigarette Tax, and Surface Water Tax in the Regulation of 3 / 2011 concerning Local Tax. DIY Province is one of the regions with the largest earmarked taxes in Java. Meanwhile, on the contrary to DIY Province, Batu City has not regulated earmarked tax in its local regulation. Although it is not the only city/regency in Indonesia, the phenomenon of Batu City describes more comprehensively to complete research concerning earmarking tax in the local tax. This research aims to analyze the implementation of earmarking tax policy on local taxes in the perspective of Fiscal Legitimacy with the case of Batu City and the Special Province of Yogyakarta.

\section{METHOD}

The paradigm used in this research is constructivist with a qualitative approach. The study was conducted in DIY Province and Kota Batu, East Java, which have different earmarking tax regulations. DIY Province has more regulations of earmarking tax than other provinces in Indonesia and has the largest number of regulations in Java Island, while Kota Batu has no regulation concerning earmarking tax on their local tax regulation. Meanwhile, according to the Law of PDRD / 2009, each regency/ city minimally has Street Illumination Tax as an earmarked tax. Qualitative data was collected through in-depth interview with key informants involved in the implementation of earmarking tax policy (stakeholders) in DIY Province and Kota Batu as well as the academicians. The data was analyzed with an illustrative method. The interview was performed in the period of October 2014 to April 2015. Meanwhile, secondary data was obtained from the relevant literary study and documentary study that includes laws and local regulations concerning the earmarking tax.

\section{RESULTS AND DISCUSSION}

Some literature has revealed the advantages and disadvantages of Earmarking tax for the government and the people. Theoretical debate over earmarking tax includes three approaches to traditional public finance, public choice and unorthodox approach each of which has the different perspective on earmarking (Wilkinson, 1994). The proponents of traditional public finance generally perceive earmarking tax as reducing the flexibility and efficiency of a budget. Public choice relates earmarking tax to public preference to particular types of public goods or services provided by the government. Unorthodox approach relates earmarking tax to such issues as fiscal legitimacy and tax morale. However, regardless of the disadvantages, results of the study have shown that earmarking is necessary to strengthen fiscal legitimacy through improvement of local government expenditure accountability. In the context of local government, Dhillon and Perroni (2000) also assured that earmarking tax policy might improve accountability.

As previously described, earmarked local tax in Indonesia include Motor Vehicle Tax and Cigarette Tax (Province) and Street Illumination Tax (regency/city). The minimal allocation is $10 \%$ of Motor Vehicle Tax for road infrastructure's maintenance and the transportation mode, $50 \%$ of Cigarette Tax for health and law enforcement, and part of the revenue from Street Illumination Tax for illumination facilities of roads and public streets. The regulation is expected to explain or inform the public about the use of local tax fund that they have paid.

Assurance for the effective expenditure of the revenue deriving from local tax in Indonesia is very crucial since at present time, the allocated budget is mostly spent on employment salary and the only small portion is for capital expenditure. DIY Province also has the highest ratio of employee salary to total expenditure in Indonesia $(56.11 \%$ ) and lowest ratio of allocation for capital expenditure $(12.59 \%)$ to total expenditure in Indonesia (DJPK, 2013). Capital expenditure has a significant effect on local economic growth 
and has the multiplier effect in improving the local economy and public welfare.

Earmarking tax policy has also ensured certainty in the budgeting of expenditure allocation from the tax revenue involving the government and the local parliament or DewanPerwakilan Rakyat Daerah (DPRD). This process is very important since decentralization of fiscal in Indonesia tend to stress on expenditure assignment characterized by a distribution of management at different levels of governments that will have an impact on the structure and portion of the local government budget. In the case of Kota Batu, the process of budgeting is a crucial point since there are institutional problems of less optimal commission in the process of budget development and relatively dysfunctional check and balance function between local government and DPRD, including the process of local expenditure policy formulation (in-depth interview, 2014).

Accountability in local government expenditure is an important point in improving compliance of tax payers that will lead to improve tax revenue (Feld and Frey, 2007; Palil, 2010, Mulgan and Murray,1993) needed by local governments due to the relatively low local tax contribution to total local revenue at province or regency/city levels (DJPK, 2013). In DIY Province, in 2013 local tax contributed to $41.2 \%$ (local budget of Province of DIY 2013) while in Batu City, local tax contributed $7,56 \%$ to total local revenue in the same period (Data from Tax Service Agency Batu City, 2015). This indicates the necessity for local government, particularly the government of Batu City to increase tax revenue through awareness rising among the people to pay tax.

Besides improving the process of budgeting, earmarking tax may also simplify public monitoring to the allocation of government budget since there has been a regulation on extent and percentage for particular types of expenditure as the reference for local government. However, of course, public monitoring is only possible when local governments provide adequate and easily accessed information for the community. Therefore, the people as the taxpayers feel sure that the government has the commitment to provide an output equivalent to tax revenue. However, in practice, public monitoring may be absent due to the lack of information about earmarking tax regulation and inadequate information on the relation between particular tax types and government's expenditure allocation (in-depth interview, 2014).

Currently, policy and regulation on of earmarking tax in local tax in DIY Province and East Java Province as the reference of earmarking tax regulation in Batu City are as follow:
Table 1. Allocation and Classification of Earmarking tax

\begin{tabular}{|c|c|c|c|c|}
\hline $\mathbf{N}$ & $\begin{array}{l}\text { Tax } \\
\text { type }\end{array}$ & $\begin{array}{l}\text { Expendit } \\
\text { ure type }\end{array}$ & $\begin{array}{c}\text { Percen } \\
\text { tage }\end{array}$ & $\begin{array}{c}\text { Characteris } \\
\text { tics* }\end{array}$ \\
\hline 1 & $\begin{array}{c}\text { Motor } \\
\text { Vehicle } \\
\text { Tax }\end{array}$ & $\begin{array}{l}\text { Developm } \\
\text { ent and/or } \\
\text { maintenan } \\
\text { ce of road } \\
\text { and } \\
\text { improvem } \\
\text { ent of } \\
\text { public } \\
\text { transportat } \\
\text { ion mode } \\
\text { and } \\
\text { facilities }\end{array}$ & $\begin{array}{c}20 \% \\
\text { (DIY) } \\
10 \% \\
\text { (UU } \\
\text { PDRD } \\
\text { ) }\end{array}$ & $\begin{array}{c}\text { Specific - } \\
\text { Loose - } \\
\text { (Rationale) } \\
\text { This type } \\
\text { has clear } \\
\text { relation } \\
\text { between } \\
\text { revenue and } \\
\text { usage. }\end{array}$ \\
\hline 2 & $\begin{array}{c}\text { Motor } \\
\text { Vehicle } \\
\text { Fuel Tax }\end{array}$ & $\begin{array}{l}\text { Mitigation } \\
\text { to air } \\
\text { pollution } \\
\text { and } \\
\text { environme } \\
\text { ntal } \\
\text { damage }\end{array}$ & $10 \%$ & $\begin{array}{c}\text { Specific - } \\
\text { Loose - } \\
\text { (Rationale) } \\
\text { Benefit } \\
\text { (Type B) }\end{array}$ \\
\hline 3 & $\begin{array}{l}\text { Surface } \\
\text { water } \\
\text { tax }\end{array}$ & $\begin{array}{l}\text { Conservat } \\
\text { ion and } \\
\text { Tree } \\
\text { Planting }\end{array}$ & $10 \%$ & $\begin{array}{c}\text { Broad - } \\
\text { Loose - } \\
\text { (Rationale) } \\
\text { There is a } \\
\text { clear } \\
\text { relation } \\
\text { between } \\
\text { paid tax and } \\
\text { beneficiaries } \\
\text {, but the } \\
\text { relation } \\
\text { between the } \\
\text { collected tax } \\
\text { and } \\
\text { expenditure } \\
\text { is in a loose } \\
\text { area. }\end{array}$ \\
\hline 4 & $\begin{array}{c}\text { Cigarett } \\
\text { e Tax }\end{array}$ & $\begin{array}{c}\text { Public } \\
\text { health } \\
\text { services } \\
\text { and law } \\
\text { enforceme } \\
\text { nt by the } \\
\text { authority. }\end{array}$ & $50 \%$ & $\begin{array}{c}\text { Broad - } \\
\text { Loose - } \\
\text { (Rationale) } \\
\text { Benefit }\end{array}$ \\
\hline 5 & $\begin{array}{c}\text { Street } \\
\text { Illumina } \\
\text { tion Tax }\end{array}$ & $\begin{array}{c}\text { Road } \\
\text { illuminati } \\
\text { on } \\
\text { services }\end{array}$ & Partial & $\begin{array}{c}\text { Specific - } \\
\text { Loose - } \\
\text { (Rationale) } \\
\text { Benefit }\end{array}$ \\
\hline
\end{tabular}

Source: Law of 28 / 2009, Local Regulation of DIY Province of 3 / 2011 and Local Regulation of East Java Province of 9 / 2011, processed. * Characteristics based on Bird and Jun (Earmarking in Theory and Korean Practice June, 2005 Richard M Bird \&Joosung Jun, p.41) 
In general, referring to Bird and Jun's criteria the earmarking tax in local tax in DIY Province and Batu City is loose. It implies that the extent of revenue of earmarked tax does not necessarily influence the extent of a specific expenditure. This is so because most of the fund derives from the general fund (in-depth interview, 2014). This condition has obscured the relation between collected tax and specific expenditure of local government. Consequently, the people do not feel the benefit from the paid tax (earmarked tax) (in-depth interview, 2014).

Based on the table, the earmarking tax may be classified into fixed and flexible, in addition to little and moderate. Fixed refers to a particular percentage specifically determined by the law and local regulation. This includes Motor Vehicle Tax, Cigarette Tax, Surface Water Tax and Motor Vehicle Fuel Tax. Meanwhile, flexibility refers to the allocation not specified in any law or local regulations as in Street Illumination Tax.

The fixed earmarking tax has advantages since it specifies clearly the allocation extent. Therefore, there is no doubt in the implementation of earmarking tax. However, fixed earmarking tax has also disadvantage since it potentially decreases the flexibility of local government to formulate the policy based on the priority scale or public need. Moreover, in such cases, the allocation extent is moderate or large $(50 \%$ or higher of tax revenue). This issue deserves attention since it is related to the concept and policy of decentralization in Indonesia. Strict regulation of earmarking tax for fixed- type with a relatively large percentage at central government level potentially results in the problem at local government level in the implementation of the policy due to the potential mismatch between the specified expenditure allocation and real need of government. This will result in difficult allocation through earmarking tax.

Meanwhile, the flexible type has advantages since it provides large flexibility to local government to arrange their own expenditure budget based on their own priority scale, vision-mission of the local head and public aspiration or need (in-depth interview, 2014). Therefore, it is expected that expenditure allocation will meet the principles of efficiency, effectiveness, and decentralization while considering public aspiration (local voice) and public choice (local choice) (Norton, 1994). However, in practice, the flexible type has disadvantages too. Regulation by a local government such as in regulation of Street Illumination Tax in Kota Batu has not clearly regulated earmarking tax. This is common in other regency/city.

Lack of regulation on the allocation extent of earmarking tax has made the position of earmarking tax weak. There is no clear difference between earmarked tax and non-earmarked tax. In addition, the position of benefit principle in earmarking tax is not clear since there is no clear relation between tax payment and benefits received by the taxpayers. This position has diminished the support of earmarking tax to the strengthening of fiscal legitimacy. The strong relation between tax and government expenditure reflects fiscal contract between the people and the government in the form of fiscal exchange.
Table 2 The Basic Concept of Pro Fiscal Legitimacy Earmarking tax

Pro Fiscal legitimacy

Benefit Principle (Mugrave, 1984) : tax is correlated to the benefits received by the people from the government or there is a connection between tax payment and government expenditure (Mulgan and Murray, 1993)

Expenditure allocation has to be accountable and easily monitored by the people (OECD, 2011) through public participation (OECD, 1994)

Earmarking tax is a formal form of contract between the people and the government or exchange between tax payment and public goods and services by the government (OECD, 2010; D’Arcy (2011)

Source: Processed from different sources, the author, 2015

Referring the previous discussion, the alternative form of earmarking tax that may strengthen fiscal legitimacy in local tax in Indonesia is flexible type at central government level to provide flexibility to local government in the design of earmarking tax policy suitable to local public needs. However, the extent has to be fixed at local government level to ensure that the substance of earmarking is accommodated in local government policy. However, caution is necessary for designing the allocation of earmarking tax to avoid inefficiency and ineffectiveness of budgeting. Therefore, the allocation extent should be between little to moderate to maintain budget flexibility in local government.

This research analyze the concept and policy of earmarking tax in attempt to support fiscal legitimacy:

Based on the concept presented in table 2, Pro Fiscal Legitimacy Earmarking tax is introduced by considering two criteria:

1. Substantive Earmarking tax Policy developed from the concept of benefit principle, fiscal contractual and tax bargain as the part of policy; and

2. Better Earmarking tax Process as a Political and social aspect developed from accountability principle being the part of good governance ;

The criteria of Substantive Earmarking tax Policy as the policy aspect imply that the design of substantive earmarking tax policy has to be based on the concepts that support earmarking tax to enhance fiscal legitimacy, which is the focus of unorthodox approach. Pro fiscal legitimacy earmarking tax is based on benefit principle by considering the relation between the paid tax and received benefit. Benefit taxation put tax in the position that resembles to price in private transaction. Implementation of this concept will put resource allocation as the direct response to public needs as public service consumers, instead of mere voters (Musgrave, 1984). Clarity of the benefit received from the paid tax will increase public obedience to pay tax (In-depth interview, 2014). Beside that, clarity of relation between tax revenue and benefits will increase public trust to the government to collect tax. Earmarking tax is an attempt to assure the taxpayers about the availability of fund for the provision of public goods and services, as well as responding the public doubt and distrust to 
the implementation of public expenditure. (In-depth interview, 2014).

In substantive earmarking policy, the preferred expenditure type has to be specific or narrow in order that the relation between paid tax and expenditure is clearly identified. In addition, the benefit will have to be directly enjoyed by the public being the tax payers in order that the public can clearly identify the benefits received from tax. This clarity will increase accountability of government's expenditure since the people can get clear and accurate information concerning government's economically rational expenditure (in-depth interview, 2014).

In designing the earmarking tax in local tax, particularly in heterogeneous community, central government will have to clarify the expenditure types and expenditure allocation percentage. This is first, more suitable with the local autonomy substance that accommodates local wisdom, and local choice and local voice. Flexible design of earmarking tax policy may accommodate heterogeneity of public characteristics, whether it is rural or urban, and allocated expenditure and thus it will be effective in meeting the public needs. Second, this will keep from mismatch between expenditure allocation and local public needs. It will accordingly support efficiency and effectiveness in the provision of public goods or services.

In pro fiscal legetimacy earmarking tax, one way to strengthen the policy of government's expenditure to fiscal legitimacy is by accommodating the participation, socialization and communication in the process of determination and reporting of government's expenditure for better accountability. Better earmarking tax is a social aspect and political aspect of the criteria of dual pro earmarking tax. Process is the important key word in dual pro earmarking tax since this process will compensate the extent of expenditure allocation of earmarking tax in order that it does not compromise budget flexibility.

Participation refers to public participation to be directly involved in the process of determination of government expenditure from earmarking tax. This involvement is important since it makes people believe that the tax revenue will result in public benefit. Participation will also help the process of identification of the expenditure types financed by particular tax revenue. In this process, the people involved will learn that the paid tax will result in public benefits instead of individual benefits. Therefore, horizontal participation may strengthen the horizontal aspect of fiscal contractual (D'Arcy, 2011).

Participation may increase public trust to the government, and therefore, it will improve the taxation performance in local government. This view is in line with the study concerning local tax conducted by Bahiigwaet al. (2004) and Ssewakirinyanga (2004) in Uganda (OECD, 2010) revealing that the key challenge to improve local taxation is reconstructing public trust through enhanced explicit relation between tax collection and public expenditure.

As a political strategy, earmarking is effective since it has impact on government accountability, transparency, and public monitoring through public participation. Therefore earmarking tax may serve the interest of political participation (OECD, 2010). Participation is a beneficial political process that enhances democratization and transparency in the determination of government's expenditure, as well as strengthens fiscal legitimacy. Participation in the determination of expenditure is also an instrument to socialize transparency and democracy in the society. Participation is necessary in local tax collection and expenditure since the relation between government and the people is direct. this is also in line with the spirit of local autonomy oriented to local public aspiration.

In the context of earmarking tax in local tax, participation is an important instrument to obtain public aspiration, which is in line with local autonomy's objective of providing public services based on local needs. Beside that, allocation of earmarking tax has to consider public characteristics, whether it is rural or urban for effective allocation of expenditure (indepth interview, 2014).

Communication refers to the government's communication to explain tax revenue and expenditure type specifically financed by particular tax. It is necessary to have good political communication from the government to support fiscal legitimacy by providing the relevant data or information. Accurate and accessible data and information is very important to increase transparency and accountability in the management of government's revenue and expenditure at national and local levels. Government will have to seek the methods suitable with the situation, condition, and culture in the communication about policy of expenditure to the public (in-depth interview, 2014).

Results of this research show that fiscal decentralization has stronger effect on tax compliance. Results of the research also show that tax morale is higher when the government provides public goods based on region or locality since the development of the region or satisfaction of the public needs (Feld and Frey, 2007).

A tax type that meets the criteria of pro fiscal legitimacy earmarking tax is property tax, particularly tax on land and building. An important fact concerning property tax commonly ignored is that in the determination of property tax may involve tax payers in political dialogue with the government. By doing so, the government may grow fiscal contract. Property tax has extensive and visible reach. Therefore, principally it is a good alternative to empower the people. Property tax has a specific relation to location and such public expenditure as infrastructure. Allocation of tax with relatively clear relation to expenditure will have good management through public empowerment and public trust development when the government meets their commitment (in-depth interview, 2014).

The selection of appropriate tax type such as Property Tax or other type with similar criteria will be advantageous for local government in the form of increased public trust. Increased public trust will contribute to the stronger fiscal legitimacy on the one hand, wile maintaining budget flexibility on the other hand since moderate or partial allocation of earmarking tax will grow public trust about the 
relatedness between the paid tax and government's expenditure.

Substantive earmarking tax policyshould maintain local government flexibility in designing the earmarking tax policy. Local governments are in charge of designing the types of local tax and expenditure regulated in local regulation and local head's regulation in compliance with public aspiration and local priority scale. Clear regulation is important to provide clarity to the public about government's expenditure financed by earmarking tax. Flexibility in designing the earmarking tax gives opportunity to local government to accommodate public aspiration being the taxpayers and avoid mismatched allocation of earmarking tax. Periodical evaluation is needed to keep the match between expenditure type and public needs. When public need for expenditure types change, local government will have to change or relocate the expenditure from earmarking tax (in-depth interview, 2014).

\section{CONCLUSION}

To improve fiscal legitimacy this research suggests the application of Pro Fiscal Legitimacy Earmarking tax. The earmarking tax policy on local taxes in Indonesia should perform the transformation of earmarking policy from symbolic earmarking tax to substantive earmarking tax. This concept of substantive earmarking tax encourages public participation and improves communication concerning tax and expenditure between government and the public. In addition, it is necessary to increase accountability and transparency of local government spending by accommodating special accounts in government accounting systems to strengthen fiscal legitimacy.

\section{REFERENCES}

[1] Abassian, Ezatollah, Gareth D. Myles. Benefit Taxation and Public Good Provision.University of Exeter and Institute for Fiscal Studies. January 23, 2006

[2] Bareno, GuglielmoBarone., SauroMocetti.Tax morale and public spending Inefficiency. International Tax and Public Financevol 18(6), pages 724-749, December 2011. Springer

[3] Becket, Julia, Francois K Doamekpor. Variability and Opportunities in Flexible Budgeting: A Local Government Approach. Public Finance and Management 11.2 (2011): 93-117.

[4] Bird, Richard M, Joosung Jun. Earmarking in Theory and Korean Practice June, 2005. ITP Paper 0513, June 2005.

[5] Bo“s, Dieter. Earmarked Taxation: Welfare versus Political Support. Journal of PublicEconomics 75 (2000) 439-462.

[6] Bryant, L. Housing affordability in Australia: an empirical study of the impact of infrastructure charges (2017) Journal of Housing and the Built Environment, 32 (3), pp. 559-579)

[7] Buchanan, James M. The Economics of Earmarked Taxes. Journal of Political Economy, Vol. 71, No. 5 (Oct., 1963), pp. 457-469. The University of Chicago Press. : http://www.jstor.org/stable/1829016

[8] Dhillon, Amrita., Carlo Perroni. Tax Earmarking and Grass-roots Accountability. University of Warwick Institutional Repository, July 2000.http:/go.warwick.ac.uk/wrap

[9] D'Arcy, Michelle. Why Do Citizens Assent to Pay Tax? Legitimacy, Taxation and The African State. Afrobarometer Working Papers, January 2011
[10] Feld, Lars P., Bruno S. Frey. Tax Compliance as the Result of a Psychological Tax Contract: The Role of Incentives and Responsive Regulation. Law and Policy Vol. 29, No. 1, January 2007 ISSN 0265 8240

[11] Hyman, David. Public Finance: A Contemporary Application of Theory to Policy, 11 th edition, 2013, Cengage learning Publisher, United States.

[12] Jackson, Jeremy Jay. The political economics of earmarked taxation. ProQuest Dissertations and Theses; 2008; ProQuest Dissertations \& Theses (PQDT). pg. n/a

[13] James, Simon and Christopher Nobes, The Economic of Taxation: Principles, Policy and Practice, 1996/1997 edition. Europe: Prantice Hall, 1996.

[14] McCleary, William. The Earmarking of Government Revenue: A Review of Some World Bank Experience. The World Bank Research Observer, vol. 6, no. 1, January 1991 pp. 81-104. The International Bank for Reconstruction and Development/ The World Bank.

[15] Michael, Joel. Earmarking State Tax Revenue. Policy Brief, Minnesota House of Representatives, Research Department 651-296-5057 January 2008.

[16] Musgrave, Richard A and Peggy B. Musgrave.Public Finance in Theory and Practice. USA: McGraw-Hill,1984

[17] Musgrave, Richard A. Horizontal Equity, Once More. National Tax Journal, Vol. 43, no. 2,(June, 1990), pp. 113-22.

[18] Neil, John R. The Benefit and Sacrifice Principles of Taxation: A synthesis. Soc Choice Welfare (2000) 17: 117 \pm 124 .Springer -Verlag 2000.OECD, 2007 :Contemporary Readings in Law and Social Justice 5.2 (2013): 656-663. Fiscal policy and legitimacy in Latin America.

[19] Rosdiana, Haula dan Slamet Irianto. Pengantar Ilmu Pajak : Kebijakan dan Implementasi di Indonesia. Jakarta: Rajawali Pers, 2012

[20] Sommerfeld, Ray M. Hersel M. Anderson and Horace R. Brock. An Introduction to Taxation. New York: Harcourt Brace JonovichInc, 1981.

[21] Trandafir, Adina, LuminitaRistea. Legitimacy and Fundamental of European Fiscal Policy. Contemporary Readings in Law and SocialJustice 5.2 (2013): 656-663. Fiscal policy and legitimacy in Latin America, OECD 2007

[22] Wilkinson, Margaret. Paying for Public Spending: Is There a Role for Earmarked Taxes?.Fiscal Studies (1994) vol. 15, no. 4, pp. 119-35

[23] DirektoratJenderalPerimbanganKeuangan, KementrianKeuangan RI, AnalisisRealisasi APBD tahunanggaran 2012, http://www.djpk.depkeu.go.id/attachments/article/390/Realisasi\% 20apbd\%202012z.pdf

[24] Peraturan Daerah Kota BatuNomor 8 Tahun 2011 TentangPokokPokokPengelolaanKeuangan Daerah.

[25] PeraturanGubernur Daerah Istimewa Yogyakarta Nomor 32 Tahun 2013 TentangRencanaKerja Pembangunan Daerah Tahun 2014

[26] PeraturanGubernur DIY Nomor 49 Tahun 2012 TentangSistem Dan ProsedurPengelolaanKeuangan Daerah

[27] PeraturanWalikotaBatuNomor $\quad 20 \quad$ Tahun 2014 TentangRencanaKerjaPemerintah Daerah Kota BatuTahun 2015 Perda Kota Batu No 9 Tahun 2011 TentangPajak Daerah

[28] Perda Kota BatuNomor 4 Tahun 2012 TentangTentangRencana Pembangunan JangkaPanjang Daerah (RPJPD) Tahun 2005 - 2009

[29] Perda Kota BatuNomor 7 Tahun 2013 TentangRencana Pembangunan JangkaMenengah Daerah Tahun 2012-2017

[30] PerdaPemerintahProvinsiJawaTimur No 9 Tahun 2010 TentangPajak Daerah PerdaProvinsi DIY No 3 Tahun 2011 TentangPajak Daerah

[31] PerdaProvinsi DIY Nomor 2 Tahun 2009 TentangRencana Pembangunan JangkaPanjangDaerah (RPJPD) Tahun 2005 - 2025

[32] PerdaProvinsi DIY Nomor 6 Tahun 2013 TentangRencana Pembangunan JangkaMenengahDaerah Tahun 2012-2016 